\title{
Dietary supplementation with carotenoids: effects on $\alpha$-tocopherol levels and susceptibility of tissues to oxidative stress
}

\author{
BY ALAN A. WOODALL"2* GEORGE BRITTON ${ }^{1}$ \\ AND MALCOLM J. JACKSON ${ }^{2} \dagger$ \\ ${ }^{1}$ Department of Biochemistry and ${ }^{2}$ Department of Medicine, University of Liverpool, PO Box 147, \\ Liverpool L69 $3 B X$
}

(Received 22 June 1995 - Revised 24 November 1995 - Accepted 5 December 1995)

\begin{abstract}
The ability of dietary supplementation with carotenoids to protect chick tissues against oxidative stress in vitro was examined. Male Leghorn chicks were fed on diets supplemented (100 $\mathrm{mg}$ supplement $/ \mathrm{kg}$ diet) with either $\beta$-carotene, zeaxanthin ( $\beta, \beta$-carotene-3,3'-diol), canthaxanthin ( $\beta, \beta$-carotene-4,4'-dione) or $\alpha$-tocopherol, or on a control diet, from $1 \mathrm{~d}$ old until $37 \mathrm{~d}$ of age. Tissues (liver, heart, skeletal muscle and plasma) were removed and assayed for total carotenoids and $\alpha$-tocopherol content and portions subjected to oxidative stress by incubation of homogenates with cumene hydroperoxide and $\mathrm{FeSO}_{4}$. Animals receiving zeaxanthin and canthaxanthin had significantly greater carotenoid concentrations in liver, heart, muscle and plasma compared with untreated controls $(P<0.05)$; animals fed on diets supplemented with $\beta$-carotene or $\alpha$-tocopherol did not have significantly different tissue carotenoid contents compared with untreated controls. $\alpha$-Tocopherol supplementation elevated $\alpha$-tocopherol levels in all tissues examined $(P<0.05)$. Supplementation with carotenoids did not affect tissue $\alpha$-tocopherol levels, but $\beta$-carotene lowered plasma $\alpha$-tocopherol levels by $50 \%(P<0.05)$. Incubation of plasma or tissue homogenates with oxidant stressors induced lipid peroxidation (production of thiobarbituric-acid reactive substances) in all tissues. Animals given $\alpha$-tocopherol, $\beta$-carotene or zeaxanthin had a reduced susceptibility to oxidant stress in liver compared with unsupplemented controls $(P<0.05)$, and $\alpha$ tocopherol-supplemented animals had reduced susceptibility in skeletal muscle compared with unsupplemented controls $(P<\mathbf{0 . 0 5})$. Canthaxanthin supplementation did not influence the susceptibility to oxidant stress in any tissue examined. These results suggest that zeaxanthin, a carotenoid present in animal and human diets, may have significant activity as an antioxidant against oxidative stress in tissues.
\end{abstract}

Carotenoids: Free radicals: Antioxidants: Vitamin E

Increasing evidence suggests that long-term oxidant stress to the body mediates chronic degenerative diseases such as cancer, cardiovascular disease, rheumatoid arthritis, cataractogenesis and autoimmune dysfunction (Ames et al. 1993). It has become apparent that factors such as smoking which lead to increased oxidant production increase the levels of oxidative damage to DNA, proteins and lipids (Sinclair et al. 1990) and also lead to increased risk of developing cardiovascular disease and cancer. Also, populations with low intakes of dietary antioxidants such as vitamin $\mathrm{E}$, vitamin $\mathrm{C}$ and $\beta$-carotene appear to be at greater risk of early development of degenerative diseases commonly associated with the

* Current address: Department of Molecular and Cell Biology, 401 Barker Hall, University of California, Berkeley, 94720, USA.

$\dagger$ For reprints. 
aged (Gey, 1993; Heliovaara et al. 1994). Hence, an imbalance between oxidative stress and antioxidant nutrient intake may be a factor in determining risk of early development of degenerative diseases.

There has been considerable interest in recent years in the potential amelioration of oxidative damage to tissues by dietary supplementation of antioxidants such as vitamin $\mathrm{E}$, vitamin $C$ and $\beta$-carotene (Gey, 1993). These studies have attempted to enhance cellular antioxidant defences by providing increased dietary intakes of compounds shown to have antioxidant activity in vitro. A number of both human and animal studies with dietary supplementation of $\beta$-carotene have demonstrated that $\beta$-carotene can protect tissues against oxidative damage. $\beta$-Carotene can protect against lipid peroxidation in cell cultures (Franke et al. 1994). Parenteral $\beta$-carotene has been shown to protect guinea-pigs against oxidative damage occurring in ascorbate deficiency (Kunert \& Tappel, 1983) and dietary supplementation with $\beta$-carotene has been shown to protect mice from lipid peroxidation induced by methyl mercuric chloride (Andersen \& Andersen, 1993) and to reduce indices of lipid peroxidation in serum (Mobarhan et al. 1990; Gottleib et al. 1993) and breath pentane exhalation (Allard et al. 1994) in human subjects.

Carotenoids other than $\beta$-carotene have been used infrequently in man since it was shown that crystalline deposits of canthaxanthin formed in the retina of human subjects ingesting this carotenoid (Boudreault et al. 1983). Supplementation of rats with astaxanthin $(1 \mathrm{~g} / \mathrm{kg}$ body weight) reduced the lysis of erythrocytes subjected to oxidant stress (Miki, 1991). Astaxanthin or $\beta$-carotene supplements lowered significantly chick plasma vitamin E levels (Lim et al. 1992) such that in the group given $\beta$-carotene the susceptibility of the plasma to 2,2'-azobis (2-amidinopropane) hydrochloride (AAPH)-induced oxidation was increased, while in the group given astaxanthin the susceptibility of the plasma to AAPHinduced oxidation was not significantly different from that of the control. On the basis of these results the authors suggested that astaxanthin but not $\beta$-carotene had equivalent antioxidant potential to vitamin $\mathrm{E}$ in plasma. The long-term effects of lowered plasma vitamin $E$ in these chicks was not determined. Other authors have also reported a reduction in plasma vitamin $\mathrm{E}$ concentration in chicks given $\beta$-carotene, but no reduction was observed in the liver vitamin E content (Mayne \& Parker, 1986). Conversely, chicks fed on a vitamin E-deficient diet but given canthaxanthin supplements were reported to have increased tissue vitamin $E$ levels compared with those animals who were maintained on a vitamin E-deficient diet alone. However, the antioxidant activity of canthaxanthin was reported to be minimal (Mayne \& Parker, 1989). Thus, it appears that minor structural changes of the carotenoid can modify its potential as an antioxidant and its effects on tocopherol metabolism in the chick.

The assessment of carotenoid antioxidant activity in vivo is limited by the lack of good animal models which can absorb both carotenes and xanthophylls efficiently. Most mammals, other than humans, chimpanzees and cattle, do not absorb both classes of carotenoids well (Olson, 1994). However, the chick has been reported to accumulate xanthophylls such as lutein, zeaxanthin, astaxanthin and canthaxanthin efficiently and can absorb a smaller amount of $\beta$-carotene, the rest of the carotene being excreted or converted into vitamin A (Marusich \& Bauernfiend, 1981). In light of previous findings which indicate that zeaxanthin is a more effective membrane antioxidant than $\beta$-carotene in cell-free systems (Lim et al. 1992; Woodall et al. 1995), we have examined the effect of dietary supplementation with $\beta$-carotene, zeaxanthin, canthaxanthin or $\alpha$-tocopherol on the susceptibility of chick tissues to oxidant stress in vitro, and on tissue $\alpha$-tocopherol levels. 

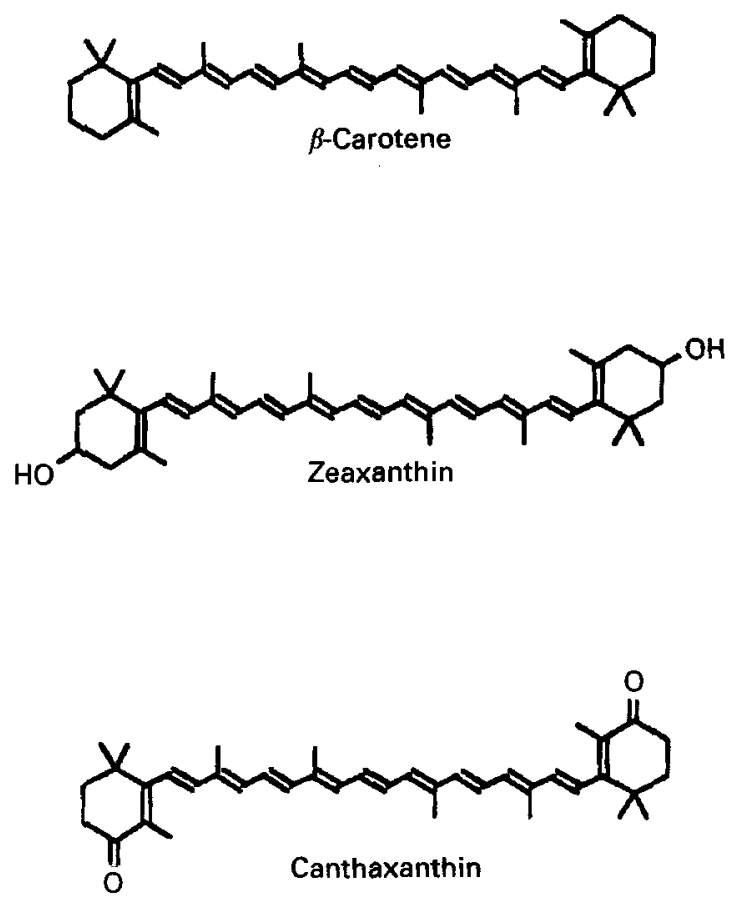

Fig. 1. Structures of carotenoids tested.

\section{MATERIALS AND METHODS}

\section{Chemicals}

Carotenoids (crystalline $\beta$-carotene, zeaxanthin and canthaxanthin, Fig. 1) were donated by F. Hoffmann-La Roche and Co. Ltd, Basle, Switzerland. Purity was confirmed by HPLC analysis. $\alpha$-Tocopherol and cumene hydroperoxide were purchased from Sigma Chemical Co., Poole, Dorset. All other reagents were of the highest purity available. Solvents for carotenoid manipulations were redistilled before use. All other solvents were of HPLC grade.

\section{Animals}

Male Leghorn chicks ( $1 \mathrm{~d}$ old $)$ were obtained from a local breeder and housed in stainless steel cages in the Biomedical Services Unit, Royal Liverpool University Hospital. Chicks were kept in groups of six for the first $14 \mathrm{~d}$ and then housed in groups of three for the remainder of the experiment. The chicks were subjected to a regime of $12 \mathrm{~h}$ light daily during the trial. Each chick was weighed at $3 \mathrm{~d}$ intervals throughout the supplementation period.

\section{Diets}

Spillers Home Range Layer Meal (Dalgety Agriculture Ltd, Bristol, Avon) was the basal meal used for dietary preparation. Feed and water were available ad libitum and changed daily. The basal diet contained two carotenoids, lutein $(4 \mu \mathrm{g} / \mathrm{kg})$ and citranaxanthin $\left(5^{\prime}, 6^{\prime}-\right.$ dihydro-5'-apo-18'-nor- $\beta$-caroten- $6^{\prime}$-one, $\left.7 \cdot 1 \mu \mathrm{g} / \mathrm{kg}\right)$, and $\alpha$-tocopherol $(6.7 \mathrm{mg} / \mathrm{kg})$. Additional carotenoids or $\alpha$-tocopherol ( $100 \mathrm{mg} / \mathrm{kg}$ diet) were dispersed in 'Mazola' maize oil (C.P.C. International Ltd, Surrey) using $20 \mathrm{~g}$ oil $/ \mathrm{kg}$ feed. Control diets were prepared with $20 \mathrm{~g}$ oil $/ \mathrm{kg}$ feed but without supplements. The diets were prepared weekly and stored in the dark. 


\section{Tissue preparation}

After $37 \mathrm{~d}$ the chicks were killed by an intraperitoneal injection of sodium pentobarbital. Blood was taken by intracardiac puncture and placed in Li-heparin tubes on ice. The thoracic and abdominal cavities were opened and the heart, liver and pectoral skeletal muscles rapidly removed. The tissues were immediately frozen in liquid $\mathbf{N}_{2}$ where they remained for up to $1 \mathrm{~h}$ before transfer to $-20^{\circ}$. Samples were stored at this temperature for up to 2 weeks before analysis. Plasma was separated from blood following centrifugation at $800 \mathrm{~g}$ for $30 \mathrm{~min}$ and stored at $-20^{\circ}$.

\section{Extraction of tissue lipid micronutrients}

Weighed tissues were added to $50 \mathrm{~mm}$-sodium phosphate buffer, $\mathrm{pH} 7 \cdot 4$, to a final concentration of about $100 \mathrm{mg} / \mathrm{ml}$. The samples were homogenized on ice (Polytron). Portions $(1 \mathrm{ml})$ of homogenate or plasma were extracted with $3.5 \mathrm{ml}$ hexane propan-2-ol $(3: 2, \mathrm{v} / \mathrm{v})$ with vortex mixing. The mixture was centrifuged at $800 \mathrm{~g}$ for $15 \mathrm{~min}$. A portion of the upper phase $(1 \mathrm{ml})$ was removed for analysis of carotenoid content and a further portion $(500 \mu \mathrm{l})$ dried down under $\mathrm{N}_{2}$ for $\alpha$-tocopherol analysis by HPLC (Phoenix $e t$ al. 1990). Overall recovery of lipid-soluble antioxidants was checked by spiking tissue homogenates from animals fed on basal diets with a known amount of $\alpha$-tocopherol before extraction. Values of 106 (SD 5) \% were obtained.

\section{$\alpha$-Tocopherol analysis by HPLC}

A Shimadzu L6A chromatograph was used with a Shimadzu SPD-6A detector coupled to a Shimadzu C-R5A integrator (Shimadzu Corp., Kyoto, Japan). The stationary phase was a $250 \mathrm{~mm}$ Spherisorb 5 ODS2 reversed phase column, internal diameter $4.6 \mathrm{~mm}$, particle size $5 \mu \mathrm{m}$ (Phase Separations Ltd, Flint, Clwyd). The mobile phase was acetonitrilemethanol-chloroform $(47: 47: 6, \mathrm{v} / \mathrm{v})$ at a flow rate of $2.5 \mathrm{ml} / \mathrm{min}$. Samples $(20 \mu \mathrm{l})$ were injected on to the column via a Rheodyne injector (Rheodyne Inc., Cotati, CA, USA). The detector was set at $292 \mathrm{~nm}$, with 0.002 AU full scale deflection. $\alpha$-Tocopherol standards were prepared in absolute ethanol. The CV of this assay was approximately $5 \%$.

\section{Carotenoid pigment analysis by HPLC}

Confirmation of the purity of carotenoid samples used for supplementation and qualitative analysis of carotenoids present in representative tissues was undertaken by reversed phase HPLC. The HPLC system employed was a Waters 660 solvent delivery system with a Waters 990 on-line multichannel photodiode array detector (Waters Chromatography, Watford, Herts.) scanning from 250-550 nm. A Spherisorb ODS2 reversed-phase column, $250 \mathrm{~mm} \times 4.6 \mathrm{~mm}$ diameter, $5 \mu \mathrm{m}$ particle size (Phase Separations Ltd) was used as the stationary phase. The mobile phase consisted of a linear gradient of $10-100 \%$ ethyl acetate in acetonitrile-water $(9: 1, \mathrm{v} / \mathrm{v})$ over $25 \mathrm{~min}$ at a flow rate of $1 \mathrm{ml} / \mathrm{min}$ with all solvents continuously purged with He.

Hexane-propan-2-ol tissue extracts were evaporated to dryness under $\mathrm{N}_{2}$. Residues were redissolved in $500 \mu \mathrm{l}$ dichloromethane and $50 \mu \mathrm{l}$ was injected on to the column. The combination of retention times and u.v.-visible absorption spectra allowed tentative identification of pigments which was confirmed, where possible, by comparison with authentic standards.

\section{Total carotenoid analysis of tissue homogenates}

Total carotenoid content of tissue or plasma was estimated spectrophotometrically from the absorbance at $450 \mathrm{~nm}$ of hexane-propan-2-ol extracts. An average millimolar 
absorption coefficient of 138 for total carotenoids was used as described previously (Britton, 1985). This technique has been employed in previous studies for quantification of total carotenoid content in biological samples (Huang \& Haug, 1974). Confirmation that carotenoids were the main pigments contributing to absorbance at $450 \mathrm{~nm}$ was confirmed by HPLC analysis of tissue extracts. An average molecular weight of 550 was used in these calculations. This was chosen to represent the mean of those carotenoids present in chick tissues. The CV of this assay was approximately $5 \%$.

\section{Susceptibility of tissue homogenates or plasma to oxidative stress}

Samples $(250 \mu \mathrm{l})$ of tissue homogenates $(100 \mathrm{mg} / \mathrm{ml})$ or plasma were mixed with $125 \mu 1$ cumene hydroperoxide $\left(20 \mu \mathrm{M}\right.$ in ethanol) and $125 \mu 1 \mathrm{FeSO}_{4}(2 \mathrm{mM}$ in distilled water) to produce a final concentration of $5 \mu \mathrm{M}$-cumene hydroperoxide and $500 \mu \mathrm{M}-\mathrm{FeSO}_{4}$ and incubated in a thermostated water bath for $2 \mathrm{~h}$ at $37^{\circ}$. Samples were then measured for thiobarbituric-acid reactive substances (TBARS). Control samples were also prepared without cumene hydroperoxide and $\mathrm{FeSO}_{4}$ and analysed immediately for basal TBARS levels.

\section{Thiobarbituric-acid reactive substances assay}

The method adopted was that of O'Farrell (1994) which was a modification of that used by Jackson et al. (1983). Basal samples and samples following incubation with oxidant stressors were each mixed with an equivalent volume of TBA reagent $(0 \cdot 61 \mathrm{M}$-trichloroacetic acid, $55.5 \mathrm{~mm}$-2-thiobarbituric acid and $1 \mathrm{~mm}$-EDTA) and the mixtures heated at $100^{\circ}$ for $12 \mathrm{~min}$, rapidly cooled on ice and the chromagen extracted into $3 \mathrm{ml}$ butan-1-ol. The formation of TBARS was measured by UV-visible spectrophotometry at $532 \mathrm{~nm}$. TBARS formation was expressed as $A_{532 \mathrm{~nm}} / \mathrm{g}$ tissue or $\mathrm{A}_{532 \mathrm{~nm}} / \mathrm{ml}$ plasma. The inter-assay $\mathrm{CV}$ of the TBARS assay was $14 \%$.

Statistics

All statistical analysis was performed by Student's $t$ test. A $P$ value of less than $0 \cdot 05$ was considered significant.

\section{RESULTS}

The chicks appeared to be healthy and showed no signs of discomfort during the feeding trial. Animal weights increased from approximately $50 \mathrm{~g}$ to $320 \mathrm{~g}$ during the trial and there was no significant difference between the body weights of the groups. At slaughter, after $37 \mathrm{~d}$ of supplementation, those animals receiving diets supplemented with zeaxanthin and canthaxanthin had noticeably increased orange-yellow pigmentation of the leg skin and beak compared with other groups. This increase in skin coloration in male chickens given zeaxanthin and canthaxanthin has been reported previously (Quackenbush et al. 1965).

Table 1 shows the total carotenoid content of chick plasma, skeletal muscle, liver and heart for animals receiving the different dietary supplements. Increased intake of $\alpha$ tocopherol or $\beta$-carotene did not alter significantly the total carotenoid content of any tissue. Increased intake of canthaxanthin and zeaxanthin elevated significantly the tissue concentration of carotenoids.

HPLC analysis with photodiode array detection was used to examine qualitatively the pigment composition of liver homogenates that contribute to absorbance at $450 \mathrm{~nm}$ in an attempt to identify the major pigments present. Examination of control liver extracts confirmed the presence of lutein and citranaxanthin in the tissue which was derived from the basal diet. A major pigment also eluted slightly after citranaxanthin (at about 15 min) with a wavelength maximum of $445 \mathrm{~nm}$ and a spectrum which retained the 'three shoulder' spectrum typical of carotenoids. From spectral shape and retention time this pigment was (tentatively) assumed to be an apo-carotenal of unknown origin. The spectral lineshape is 
Table 1. Total carotenoid content of tissues from chicks fed on a control diet or diets supplemented with $\alpha$-tocopherol or carotenoids $(100 \mathrm{mg} / \mathrm{kg})$ for $37 \mathrm{~d}$

(Mean values with their standard errors for five chicks per group)

\begin{tabular}{|c|c|c|c|c|c|c|c|c|}
\hline \multirow[b]{2}{*}{ Supplement } & \multicolumn{2}{|c|}{$\begin{array}{c}\text { Plasma } \\
(\mu \mathrm{mol} / 1)\end{array}$} & \multicolumn{2}{|c|}{$\begin{array}{c}\text { Liver } \\
(\mu \mathrm{mol} / \mathrm{kg})\end{array}$} & \multicolumn{2}{|c|}{$\begin{array}{c}\text { Skeletal } \\
\text { muscle } \\
(\mu \mathrm{mol} / \mathrm{kg})\end{array}$} & \multicolumn{2}{|c|}{$\begin{array}{c}\text { Heart } \\
(\mu \mathrm{mol} / \mathrm{kg})\end{array}$} \\
\hline & Mean & $\mathbf{S E}$ & Mean & $\mathrm{SE}$ & Mean & $\mathbf{S E}$ & Mean & SE \\
\hline Control & $4 \cdot 51$ & 0.81 & $10 \cdot 04$ & 1.62 & 1.89 & 0.22 & $4 \cdot 33$ & 0.09 \\
\hline$\alpha$-Tocopherol & 4.86 & 0.64 & $10 \cdot 72$ & 0.47 & $2 \cdot 05$ & 0.22 & $4 \cdot 47$ & 0.47 \\
\hline$\beta$-Carotene & $5 \cdot 78$ & 0.51 & 16.96 & 1.65 & $2 \cdot 73$ & $0 \cdot 13$ & $4 \cdot 56$ & 0.40 \\
\hline Zeaxanthin & $27 \cdot 18 \uparrow$ & 1.72 & $67 \cdot 29 * * *$ & 7.53 & $13 \cdot 60 \dagger$ & $1 \cdot 22$ & $16 \cdot 27 * * *$ & $1 \cdot 13$ \\
\hline Canthaxanthin & $12 \cdot 53^{* * *}$ & 1.54 & $31 \cdot 73 \dagger$ & 1.58 & $5 \cdot 53^{* * *}$ & 0.43 & $9.98 * *$ & 0.87 \\
\hline
\end{tabular}

Mean values were significantly different from the corresponding control: ${ }^{*} P<0 \cdot 01, * * * P<0.001$, $\dagger P<0.0001$.

Table 2. $\alpha$-Tocopherol content of tissues from chicks fed on a control diet, or diets supplemented with $\alpha$-tocopherol or carotenoids $(100 \mathrm{mg} / \mathrm{kg})$ for $37 \mathrm{~d}$

(Mean values with their standard errors for five chicks per group)

\begin{tabular}{|c|c|c|c|c|c|c|c|c|}
\hline \multirow[b]{2}{*}{ Supplement } & \multicolumn{2}{|c|}{$\begin{array}{l}\text { Plasma } \\
(\mu \mathrm{mol} / 1)\end{array}$} & \multicolumn{2}{|c|}{$\begin{array}{c}\text { Liver } \\
(\mu \mathrm{mol} / \mathrm{kg})\end{array}$} & \multicolumn{2}{|c|}{$\begin{array}{c}\text { Skeletal } \\
\text { muscle } \\
(\mu \mathrm{mol} / \mathrm{kg})\end{array}$} & \multicolumn{2}{|c|}{$\begin{array}{c}\text { Heart } \\
(\boldsymbol{\mu} \mathrm{mol} / \mathrm{kg})\end{array}$} \\
\hline & Mean & $\mathbf{S E}$ & Mean & $\mathbf{S E}$ & Mean & $\mathrm{SE}$ & Mean & SE \\
\hline Control & $3 \cdot 1$ & $0 \cdot 3$ & $15 \cdot 1$ & $4 \cdot 8$ & $10 \cdot 6$ & $1 \cdot 5$ & $15 \cdot 9$ & $4 \cdot 9$ \\
\hline$\alpha$-Tocopherol & $12 \cdot 5^{* *}$ & $1 \cdot 1$ & $54 \cdot 6^{* *}$ & $6 \cdot 3$ & $24 \cdot 9 *$ & $1 \cdot 1$ & $106 \cdot 3^{* *}$ & $7 \cdot 9$ \\
\hline$\beta$-Carotene & $1 \cdot 7^{* *}$ & $0 \cdot 1$ & $15 \cdot 2$ & $2 \cdot 7$ & $9 \cdot 2$ & 3.7 & $6 \cdot 1$ & 0.4 \\
\hline Zeaxanthin & $2 \cdot 3$ & $0 \cdot 3$ & $14 \cdot 9$ & $4 \cdot 5$ & $11 \cdot 1$ & $3 \cdot 0$ & $7 \cdot 1$ & 0.4 \\
\hline Canthaxanthin & $3 \cdot 1$ & 0.5 & $13 \cdot 7$ & $3 \cdot 7$ & $9 \cdot 6$ & $3 \cdot 3$ & $9 \cdot 1$ & $1 \cdot 1$ \\
\hline
\end{tabular}

Mean values were significantly different from the corresponding control: ${ }^{*} P<0.05, * * P<0.01$.

not typical of other pigments such as bilirubin which have a wavelength maximum at $450 \mathrm{~nm}$, but a broad spectrum without the lineshape typical of the carotenoids. This pigment was observed in liver lipid extracts from all supplemented groups. HPLC analysis of liver extracts of animals given $\beta$-carotene revealed that this pigment was assimilated to a small extent in this tissue. This pigment also co-eluted with a compound which, by wavelength maximum $(350 \mathrm{~nm})$ and retention time, may have been a retinyl ester. HPLC analysis of lipid extracts of the two xanthophylls, zeaxanthin and canthaxanthin, confirmed that these pigments were the major components with absorbance at $450 \mathrm{~nm}$ in these extracts.

Table 2 shows the effects of these carotenoid and tocopherol supplements on the $\alpha$ tocopherol content of plasma, skeletal muscle, liver and heart. Animals receiving the $\alpha$ tocopherol-supplemented diet had 2-3-fold elevated $\alpha$-tocopherol levels. Feeding carotenoid-supplemented diets did not alter significantly the solid-tissue $\alpha$-tocopherol levels, but animals receiving the $\beta$-carotene-supplemented diet had significantly lower plasma $\alpha$ tocopherol levels $(P<0 \cdot 05)$.

Possible protective effects of dietary supplementation with these micronutrients against 


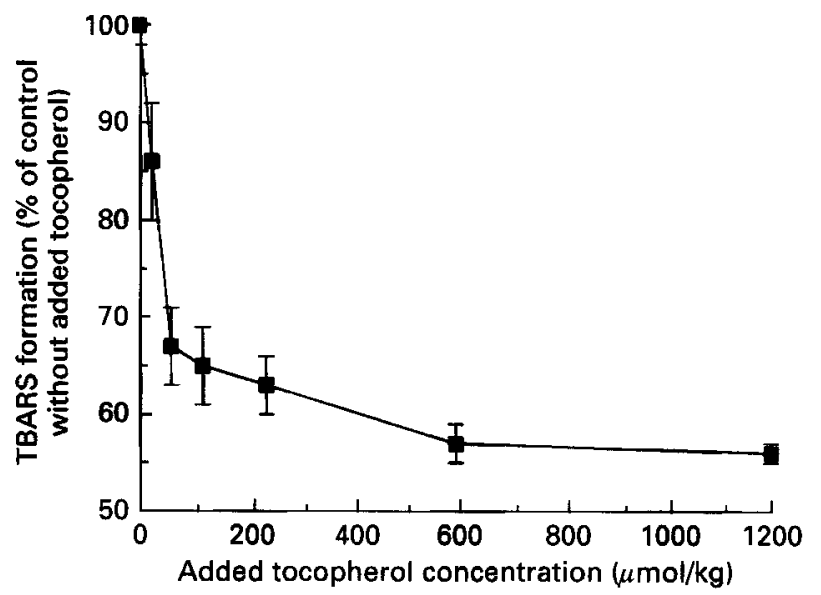

Fig. 2. Effect of exogenous $\alpha$-tocopherol on susceptibility of chick liver homogenates to oxidation by cumene hydroperoxide $(5 \mu \mathrm{M})$ and $\mathrm{FeSO}_{4}(500 \mu \mathrm{M})$. TBARS, thiobarbituric-acid reacting substances. Values are means for three samples, with their standard errors represented by vertical bars.
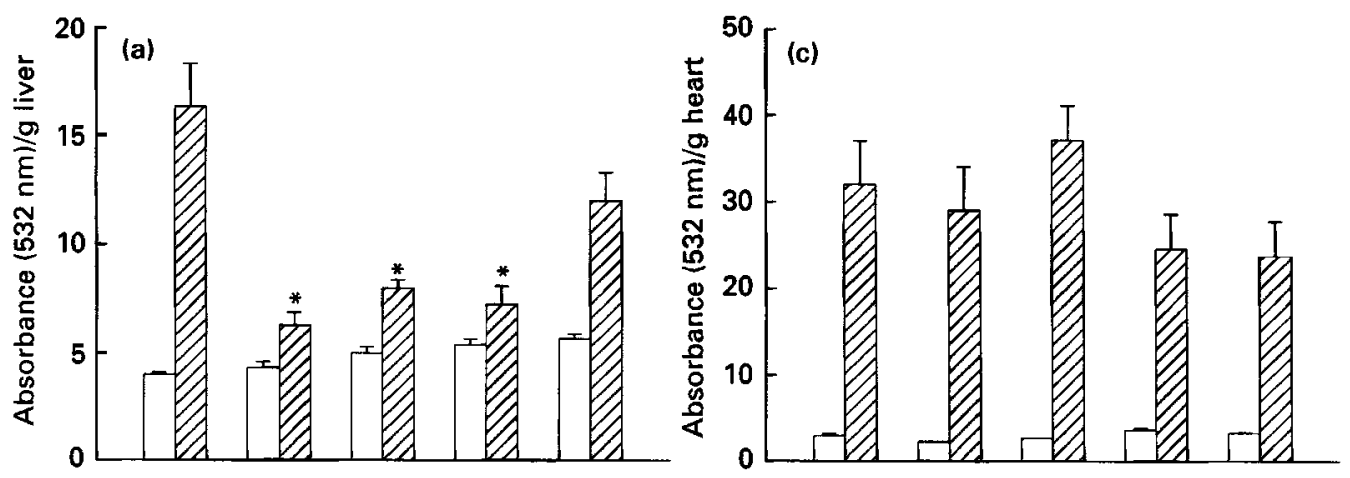

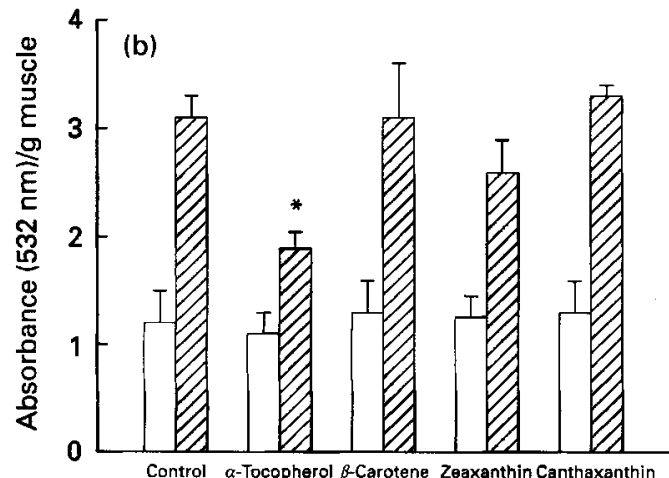

Supplement

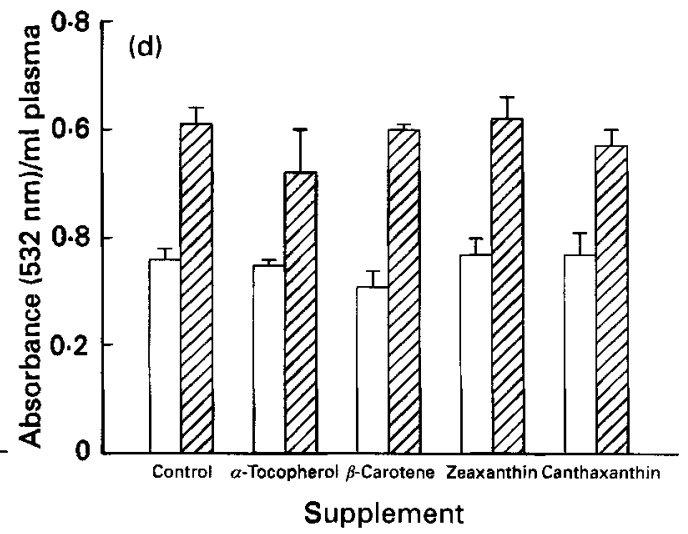

Fig. 3. Effect of dietary supplementation with $\alpha$-tocopherol or carotenoids $(100 \mathrm{mg} / \mathrm{kg}$ feed) on the oxidative susceptibility of (a) chick liver, (b) skeletal muscle, (c) heart and (d) plasma incubated with cumene hydroperoxide and $\mathrm{FeSO}_{4}$. Basal thiobarbituric-acid reacting substances (TBARS) content ( $\square$ ) and TBARS produced following incubation with radical stressors for $2 \mathrm{~h}$ at $37^{\circ}(\bigotimes)$. Values are means for five chicks, with their standard errors represented by vertical bars. ${ }^{*}$ Mean values were significantly different from the corresponding control, $P<0.05$. 
oxidative stress were assessed by measurement of TBARS production following incubation of tissue homogenates and plasma with cumene hydroperoxide and $\mathrm{FeSO}_{4}$. In order to evaluate the sensitivity of this assay, liver homogenates taken from control chicks were incubated with different amounts of exogenous $\alpha$-tocopherol (Fig. 2). Exogenous $\alpha$ tocopherol at concentrations greater than $20 \mu \mathrm{mol} / \mathrm{kg}$ liver significantly decreased TBARS formation $(P<0.05)$. Concentrations of $\alpha$-tocopherol above $250 \mu \mathrm{mol} / \mathrm{kg}$ liver did not further reduce TBARS formation. Hence, there may be a limit to the inhibition of lipid peroxidation which is attainable with $\alpha$-tocopherol supplements. The $\alpha$-tocopherol content of unsupplemented chick liver was $15 \cdot 1$ (SE 4.8) $\mu \mathrm{mol} / \mathrm{kg}$ (Table 2) and addition of an extra $20 \mu \mathrm{mol} / \mathrm{kg}$ therefore reflects an approximate doubling of the liver $\alpha$-tocopherol levels. Supplementation with $\alpha$-tocopherol raised chick liver $\alpha$-tocopherol levels to about $50 \mu \mathrm{mol} / \mathrm{kg}$ tissue (Table 2). The method employed to assess susceptibility of tissues to oxidative stress should therefore be sufficiently sensitive to detect modifications of this magnitude in tissue antioxidant capacity.

Fig. 3 shows the effect of dietary supplementation with $\alpha$-tocopherol and carotenoids on the susceptibility of chick tissues to oxidative stress in liver (a), skeletal muscle (b), heart (c) and plasma (d). There was no significant difference between the basal (unstressed) tissue TBARS levels of animals fed on unsupplemented and supplemented diets. However, when tissues were incubated with radical stressors, TBARS formation was significantly lower in the liver of animals given $\alpha$-tocopherol, $\beta$-carotene or zeaxanthin, but not canthaxanthin (Fig. 3(a)). Animals fed on $\alpha$-tocopherol-supplemented diets also had a significantly reduced TBARS formation in skeletal muscle samples compared with unsupplemented controls, although carotenoid supplementation had no protective effect in skeletal muscle (Fig. 3(b)). No significant effects of dietary supplementation with $\alpha$-tocopherol or carotenoids were seen on the TBARS formed in heart homogenate or plasma after incubation with stressors (Figs 3(c) and 3(d)).

\section{DISCUSSION}

$\alpha$-Tocopherol, ascorbate and $\beta$-carotene have received considerable attention as putative antioxidants with the ability to attenuate oxidative stress and ameliorate the cellular dysfunction that results from oxidative damage to cellular constituents, but other potential antioxidants in the diet have not been examined fully. $\beta$-Carotene is only one of a number of carotenoids in the human diet; others such as lycopene, lutein, $\beta$-cryptoxanthin and zeaxanthin are also absorbed at concentrations similar to, and sometimes exceeding that of $\beta$-carotene. Experiments in vitro have demonstrated that these other carotenoids can be more effective antioxidants than $\beta$-carotene (Di Mascio et al. 1989; Terao, 1989; Woodall et al. 1995).

Supplementation with $\alpha$-tocopherol, $\beta$-carotene, canthaxanthin, or zeaxanthin $(100 \mathrm{mg}$ micronutrient $/ \mathrm{kg}$ diet) produced no apparent physiological dysfunction in the chicks consuming the diets, apart from carotenodermia and carotenaemia in those animals on zeaxanthin- or canthaxanthin-supplemented diets.

Supplementation of basal diets with $\alpha$-tocopherol increased significantly the concentration of this micronutrient in plasma, liver, heart and skeletal muscle. Tocopherols are essential nutrients in chickens, preventing a range of degenerative disorders which otherwise occur in avitaminosis-E. Addition of exogenous $\alpha$-tocopherol ( $23 \mu \mathrm{mol} / \mathrm{kg}$ liver $)$ to liver homogenates undergoing oxidative stress reduced the level of TBARS formation and as expected the dietary supplementation with $\alpha$-tocopherol reduced liver TBARS formation in vitro.

Supplementation of basal diets with zeaxanthin and canthaxanthin raised significantly 
total carotenoid levels in all tissues examined (plasma, liver, skeletal muscle and heart). These xanthophylls have been reported to accumulate in chicks supplemented with these pigments (Marusich \& Bauernfiend, 1981). Examination of the carotenoid composition of liver from animals fed on diets supplemented with zeaxanthin or canthaxanthin confirmed that the carotenoid given was the predominant carotenoid present in the tissue. The highest carotenoid concentration was observed in liver, with zeaxanthin supplementation raising the liver total carotenoid content to approximately $70 \mu \mathrm{mol} / \mathrm{kg}$. This suggests that any effects of carotenoid supplementation to protect against oxidative stress should be most apparent in the liver.

$\alpha$-Tocopherol supplementation did not change significantly total carotenoid levels in any tissue and feeding animals zeaxanthin or canthaxanthin did not significantly alter $\alpha$ tocopherol levels in any tissue. Uptake of these compounds from the diet may therefore be independent from $\alpha$-tocopherol, and thus dual supplementation of tocopherol and xanthophylls may significantly raise tissue levels of both classes of compounds. This may be important in terms of maximizing defences against oxidative damage to tissues, since tocopherols are more efficient at trapping free radicals than are carotenoids (Terao, 1989; Lim et al. 1992; Palozza \& Krinsky, 1992), but carotenoids are more efficient than $\alpha-$ tocopherol at physical quenching of singlet oxygen (Di Mascio et al. 1989) and at scavenging sulphur radicals (D'Aquino et al. 1989). Hence, in tissues where both oxidant species are likely to be generated (such as skin subjected to high levels of u.v. light), combined supplementation with $\alpha$-tocopherol and zeaxanthin may be more effective in minimizing oxidative damage.

Supplementation of diets with $\beta$-carotene did not appear to raise significantly total carotenoid levels in any tissue examined, probably because $\beta$-carotene is cleaved efficiently in the chick intestinal mucosa to vitamin A (Olson, 1994). Some $\beta$-carotene was observed in liver extracts from $\beta$-carotene-supplemented animals on HPLC analysis, but this uptake was insufficient to influence significantly the measured total carotenoid content of the samples. $\beta$-Carotene supplementation lowered significantly the $\alpha$-tocopherol content of plasma by about $50 \%$. This effect of $\beta$-carotene on tocopherol levels in plasma but not in tissues has been reported previously in chicks (Mayne \& Parker, 1986) and humans (Xu et al. 1992). Whether this decrease in plasma $\alpha$-tocopherol is a direct action of $\beta$-carotene is not known.

No differences in basal TBARS were observed in the plasma or other tissues of animals on any diets. It is likely that there is a low level of unavoidable continuous oxidative damage in tissues. Since cells maintain multiple antioxidant defence mechanisms which cannot prevent this low level of oxidative damage, the effects of a minor increase in one dietary antioxidant are probably not significant, as not every free radical can be trapped. Another possibility is that the TBARS assay is not sufficiently sensitive to detect such minor differences (Gutteridge, 1986).

When liver samples were subjected to oxidative stress, protection (in terms of a lower TBARS formation) was conferred by dietary supplementation with $\alpha$-tocopherol, $\beta$ carotene and zeaxanthin. $\alpha$-Tocopherol was the most effective in this, significantly lowering the formation of TBARS to $15 \%$ of that of the unsupplemented control. Formation of TBARS in the liver of animals given zeaxanthin and $\beta$-carotene-supplemented diets was $22 \%$ of that of the unsupplemented control in both cases. Canthaxanthin supplementation however, did not significantly protect the liver from ex vivo oxidation, although there was a trend towards protection which just failed to reach significance $(P=0.07)$. This relatively poor antioxidant effect of canthaxanthin in chick liver subjected to oxidative stress has also been reported previously (Mayne \& Parker, 1989). In no other tissue was there any protective effect of dietary supplementation with $\alpha$-tocopherol or carotenoids, except in the 
skeletal muscle of chicks given $\alpha$-tocopherol where TBARS formation was lowered compared with that in unsupplemented controls.

Thus, dietary supplementation with $\alpha$-tocopherol, zeaxanthin and $\beta$-carotene reduced the susceptibility of the liver to free-radical-induced oxidative damage in vitro. It is interesting to note that $\alpha$-tocopherol was the most effective at protecting skeletal muscle against oxidation, which is in agreement with other studies indicating that this compound is more effective than carotenoids as a radical-trapping antioxidant. Zeaxanthin was also found to be more effective than canthaxanthin at protecting tissues against oxidation. However, zeaxanthin appeared to accumulate more readily than canthaxanthin in all tissues. Nevertheless, this study is the first to demonstrate protection of a tissue by dietary supplementation with zeaxanthin.

One surprising result was the apparent protective effect of $\beta$-carotene supplementation on the susceptibility of liver to oxidative damage, since $\beta$-carotene supplements did not elevate significantly the total carotenoid content of the tissue. A possible explanation for this is that supplementation with $\beta$-carotene, but not other carotenoids may have increased liver retinyl ester levels. Vitamin $\mathrm{A}$ has been shown to have antioxidant activity in vitro (Tesoriere et al. 1993) and hence, an increase in retinyl ester levels may have afforded increased protection against oxidative damage in liver. The apparent protective activity of zeaxanthin cannot be attributed to increased vitamin A levels, as this compound is not a precursor of vitamin A. The antioxidant activity of zeaxanthin is therefore likely to be directly related to properties of the zeaxanthin molecule.

Thus, these results demonstrate that dietary supplementation with carotenoids other than $\beta$-carotene can protect tissues which accumulate these pigments against induced oxidative damage, presumably by the carotenoid acting as a lipid-soluble antioxidant. These findings also suggest that zeaxanthin is an effective dietary antioxidant in the chick. Whether zeaxanthin supplements will also increase antioxidant capacity in mammals is unknown. Further examination of the antioxidant efficacy of supplementation with zeaxanthin and carotenoids other than $\beta$-carotene (e.g. lycopene, lutein and $\beta$ cryptoxanthin) are warranted.

This work was supported by the Wellcome Trust Prize Studentship awarded to A. A.W. The authors would also like to thank Dr G. A. J. Pitt for valuable discussions in the course of this work.

\section{REFERENCES}

Allard, J. P., Royall, D., Kurian, R., Muggli, R. \& Jeejeebhoy, K. N. (1994). Effects of $\beta$-carotene supplementation on lipid peroxidation in humans. American Journal of Clinical Nutrition 59, 884-890.

Ames, B. N., Shigenaga, M. K. \& Hagen, T. M. (1993). Oxidants, antioxidants and the degenerative diseases of aging. Proceedings of the National Academy of Sciences USA 90, 7915-7922.

Andersen, H. R. \& Andersen, O. (1993). Effects of dietary alpha-tocopherol and beta-carotene on lipid peroxidation by methyl mercuric chloride in mice. Pharmacology and Toxicology 73, 192-201.

Boudredault, G., Cortin, P., Corrieveau, L. A., Rousseau, A. P., Tardif, Y. \& Malefant, M. (1983). The retinopathy of canthaxanthine. 1. Clinical study of 51 users. Canadian Journal of Ophthalmology 18, 325-328.

Britton, G. (1985). General carotenoid methods. Methods in Enzymology 111, 113-149.

D’Aquino, M., Dunster, C. \& Willson, R. L. (1989). Vitamin A and glutathione-mediated free radical damage: competing reactions with polyunsaturated fatty acids and vitamin C. Biochemical and Biophysical Research Communications 161, 1199-1203.

Di Mascio, P., Kaiser, S. \& Sies, H. (1989). Lycopene as the most efficient biological carotenoid singlet oxygen quencher. Archives of Biochemistry and Biophysics 274, 532-538.

Franke, A. A., Harwood, P. J., Shimamoto, T., Lumeng, S., Zhang, L. X., Bertram, J. S., Wilkens, L. R., Lemarchand, L. \& Cooney, R. V. (1994). Effects of micronutrients and antioxidants on lipid peroxidation in human plasma and cell culture. Cancer Letters 79, 17-26.

Gey, K. F. (1993). Prospects for the prevention of free radical disease, regarding cancer and cardiovascular disease. British Medical Bulletin 49, 679-699. 
Gottleib, K., Zarling, E. J., Mobarhan, S., Bowen, P. \& Sugerman, S. (1993). Beta carotene decreases markers of lipid peroxidation in healthy volunteers. Nutrition and Cancer 19, 207-212.

Gutteridge, J. M. C. (1986). Iron promoters of the Fenton reaction can be released from haemoglobin by peroxides. FEBS Letters 201, 291-295.

Haung, L. \& Haug, A. (1974). Regulation of membrane fluidity in Acholeplasma laidawiae; effect of carotenoid pigment content. Biochimica et Biophysica Acta 352, 361-370.

Heliovaara, M., Knekt, P., Aho, K., Aaran, R. K., Alfthan, G. \& Aroma, A. (1994). Serum antioxidants and risk of rheumatoid arthritis. Annals of Rheumatoid Diseases 53, 51-53.

Jackson, M. J., Jones, D. A. \& Edwards, R. H. T. (1983). Lipid peroxidation of skeletal muscle: an in vitro study. Bioscience Reports 3, 609-619.

Kunert, K. J. \& Tappel, A. L. (1983). The effect of vitamin C on in vivo lipid peroxidation in guinea pigs as measured by pentane and ethane production. Lipids 18, 271-274.

Lim, B. P., Nagao, A., Terao, J., Tanaka, K., Suzuki, T. \& Takama, K. (1992). Antioxidant activity of xanthophylls on peroxyl radical-mediated phospholipid peroxidation. Biochimica et Biophysica Acta 1126, $178-184$.

Marusich, W. L. \& Bauernfiend, J. C. (1981). Oxycarotenoids in poultry feed. In Carotenoids as Colorants and Vitamin A Precursors, pp. 320-441 [J. Bauernfiend, editor]. New York: Academic Press.

Mayne, S. T. \& Parker, R. S. (1986). Subcellular distribution of $\beta$-carotene in chick liver. Lipids 21, $164-169$.

Mayne, S. T. \& Parker, R. S. (1989). Antioxidant activity of dietary canthaxanthin. Nutrition and Cancer 12. $225-236$.

Miki, W. (1991). Biological functions and actions of animal carotenoids. Pure and Applied Chemistry 63, $141-146$.

Mobarhan, S., Bowen, P., Anderson, B., Evans, M., Stacewicz-Sapuntzakis, M., Sugerman, S., Simms, P., Lucchesi, D. \& Friedman, H. (1990). Effects of $\beta$-carotene repletion on $\beta$-carotene absorption, lipid peroxidation and neutrophil superoxide formation in young men. Nutrition and Cancer 14, 195-206.

O'Farrell, S. (1994). Dietary polyunsaturated fatty acids and oxidative damage to heart, skeletal muscle and skin. PhD Thesis, Liverpool University.

Olson, J. A. (1994). Absorption, transport and metabolism of carotenoids in humans. Pure and Applied Chemistry 66, 1101-1106.

Palozza, P. \& Krinsky, N. I. (1992). Antioxidant effects of carotenoids in vivo and in vitro: an overview. Methods in Enzymology 213, 403-419.

Phoenix, J., Edwards, R. H. T. \& Jackson, M. J. (1990). Effects of calcium ionophore on vitamin E deficient muscle. British Journal of Nutrition 64, 245-256.

Quackenbush, F. W., Kvakovsky, S., Hoover, T. \& Rogler, J. C. (1965). Deposition of individual carotenoids in avian skin. Journal of the Association of Official Agricultural Chemists 48, 1241-1244.

Sinclair, A. J., Barnett, A. H. \& Lunec, J. (1990). Free radicals and antioxidant systems in health and disease. British Journal of Hospital Medicine 43, 334-344.

Terao, J. (1989). Antioxidant activity of $\beta$-carotene related carotenoids in organic solution. Lipids 24, 659-661.

Tesoriere, L., Ciaccio, M., Bongiorno, A., Riccio, A., Pintaudi, A. M. \& Livrea, M. A. (1993). Antioxidant activity of all-trans-retinol in homogenous solution and in phosphatidylcholine liposomes. Archives of Biochemistry and Biophysics 307, 217-223.

Woodall, A. A., Britton, G. \& Jackson, M. J. (1995). The antioxidant activity of carotenoids in phosphatidylcholine vesicles: chemical and structural considerations. Biochemical Society Transactions 23, 133.

Xu, M. J., Plezia, P. M., Alberts, D. S., Emerson, S. S., Peng, Y. M., Sayers, S. M., Liu, Y., Rittenbaugh, C. \& Gensler, H. L. (1992). Reduction in plasma or skin alpha-tocopherol concentrations with long-term oral administration of beta-carotene in humans and mice. Journal of the National Cancer Institute 84, 1559-1565. 